\title{
Education Media Videos and Posters on Healthy Snacks Behavior In Elementary Schools Students
}

\author{
Eva Mayasari, Riska Epina Hayu*, Ika Permanasari \\ STIKes Al Insyirah, Indonesia \\ *riskaepinahayu@ymail.com
}

\begin{abstract}
Healthy food is food that contains substances needed by the body. Healthy foods contain balanced nutrition, which is food that is full of nutrients and is well consumed by the body. Healthy food is the right food to add nutrients to our body, which contains nutrients such as carbohydrates, proteins, fats, vitamins, minerals and water. Generally habits that often become a problem are eating habits in the cafeteria or shop around the school and fast food eating habits. In order to overcome the unhealthy habits of school children, the role of the media in health promotion is needed. Media commonly used such as video media and posters, which are expected to help change student behavior. This study aims to determine the effect of video media and posters on healthy snack behavior of elementary school students. The design used in this study is quasi experiment with one pre-and post-village design. The results of the study obtained media health education through video and posters had a positive influence on knowledge $(\mathrm{p}=0,000)$, attitude $(\mathrm{p}=0.003)$, and actions $(\mathrm{p}=0.002)$ of students in choosing healthy snacks. Students' knowledge before intervention is mostly in the good category and increases after being given health education through videos and posters. Media of health education through video and posters has a positive influence on the knowledge, attitudes and actions of students in choosing healthy snacks.
\end{abstract}

Keywords : Education Media, Behavior, Healthy snacks. 


\section{STRADA Jurnal Ilmiah Kesehatan}

DOI: $10.30994 /$ sjik.v9i2.229

ISSN: 2252-3847 (print); 2614-350X (online)

Vol.9 No.2 November 2020 Page.543-550

\section{BACKGROUND}

School-age children are the next generation who are investing in improving the welfare of the nation, therefore it is necessary to improve their health. Providing adequate and good quality nutrition can optimize the growth and development of school-age children. Solid activities ranging from morning to evening, ranging from school activities to the various courses that are followed require the child to keep up the spirit of living it.

Breakfast is highly recommended for children before activities. Some reasons for not eating breakfast include late waking up, distance from school, not eating. Children who do not eat breakfast will have a central nervous system imbalance followed by dizziness, trembling and fatigue. If this happens the child will have difficulty receiving lessons.

The consumption of elementary school children who are often found in general is like snacking at school and at home do not want to eat. Parents usually give children snacks, so that children can buy whatever snacks sold at school. In addition, children generally do not eat breakfast, eat lunch outside the home, are not regular and do not meet nutritional needs. This will affect the child's appetite at home and can cause children to be malnourished.

Snack food is food and food processed by food craftsmen at the point of sale and or served as ready-to-eat food for sale to the public other than those served catering services, restaurants / hotels, and hotels (Minister of Health Decree No. 942 / MenKes / SK / VII / 2003). Snack food is food and drink prepared and / or sold by street vendors in the streets and other public places that are directly eaten or consumed then without further processing or preparation (Yasmin et al., 2010).

Healthy food is food that contains substances needed by the body. Healthy foods contain balanced nutrition, which is food that is full of nutrients and is well consumed by the body. Healthy food is the right food to add nutrients to our body, which contains nutrients such as carbohydrates, proteins, fats, vitamins, minerals and water (Hardani, 2012). A balanced menu is a menu that consists of a variety of foods in the appropriate number and proportion, so as to meet one's nutritional needs in order to maintain and repair body cells and life processes and growth and development (Almatsier, 2009). Scientists estimate $75 \%$ of cancers can be prevented through a better diet. Incorrect food consumption can make the body lack the vital nutrients needed for the body to work properly. The key to good health is a balanced and varied diet. The caloric needs of elementary school children are 1500-2000 kcal per day, depending on age group. To meet these energy needs can be obtained from food provided at home and from snacks. Schoolchildren need more or less the same food as those recommended for pre-school children unless the portion has to be larger because their needs are more due to their weight gain and activities (Pudjiadi, 2000).

According to Sihadi (2004) snacking habits that have spread among schoolchildren do not need to be eliminated, because snacks are a good vehicle to increase nutrient intake. Both parents and the school simply monitor and tell the types of snacks that are well consumed. Consumption of snacks that are good for health can complement or add to the nutritional needs of children. In addition to filling the stomach void, because every 3-4 hours after eating, the stomach starts to empty. Finally, if not given a snack, the child cannot refocus his mind on the lessons given by the teacher in the class.

In general, habits that often become a problem are eating habits in the cafeteria or shop around the school and fast food eating habits. Snack food sold by street vendors according to FAO (food and agriculture organization) is defined as food and beverages prepared and sold by street vendors in the streets and in other public places that are 


\section{STRADA Jurnal Ilmiah Kesehatan}

DOI: $10.30994 /$ sjik.v9i2.229

ISSN: 2252-3847 (print); 2614-350X (online)

Vol.9 No.2 November 2020 Page.543-550

directly eaten or consumed without further processing or preparation. School children generally spend $1 / 4$ time in school, and are more exposed to street food snacks.

Street hawker foods contribute energy intake for school children as much as $36 \%$, $29 \%$ protein and iron $52 \%$. Therefore, it can be understood the important role of street food hawker in the growth and learning achievement of school children. However, the safety of the snacks both in terms of microbiology and chemistry is still questionable. Based on data obtained from the Center for Drug and Food Control (BPBPOM) as many as 21 cases of dangerous school food snacks (PJAS) were found while conducting sampling tests on food sold in elementary school canteens in Riau. Of the 144 samples tested for feasibility, there were 21 of them containing dangerous substances, such as borak and formalin. Thus, to reduce the exposure of school children to unhealthy snacks, efforts should be made to promote food security to schools, teachers, parents, students and traders.

Media in health promotion has a role as a means of building an atmosphere conducive to positive behavioral change. Health promotion is carried out using various methods and media that are carried out on target. Media that can be used such as videos, posters and leaflets are widely used in health promotion practices. Videos can present information, describe processes, explain complex concepts, teach skills, shorten or extend time and influence attitudes. While posters have the ability to increase awareness of health and can stimulate trust, attitudes and behavior.

This research will be conducted on students of SDN Pekanbaru class V and VI. Based on the initial survey conducted, it is known that many traders who sell in the school environment do not pay attention to the cleanliness and quality of the food sold. Meanwhile most students buy their snacks. And based on the information received, the school has given reprimands and appeals to traders to pay more attention to the cleanliness and quality of the merchandise but there has been no change. Therefore, researchers want to intervene in students so that they can choose safe and healthy snacks.

\section{METHODS}

The research starts from the preparation stage, research design, permit application to data processing. The program stages begin with studies that are used to help research, then observed to find preliminary data, after which problems are called focus, to then get a suitable research design. The data processing stage is carried out through a process and explores by studying documents, processes and interviews. This research will be carried out at SDN 21 Pekanbaru.. This study uses a quantitative approach that is by using a questionnaire to determine statistically differences in consumption behavior of snacks among students between before and after the intervention using video media and posters. The design used in this study is quasi experiment with one pre-and post-village design.

Data collection techniques using a questionnaire about the consumption behavior of snacks, measured by the following method: the component of knowledge is measured by 13 items of questions with the type of answer choices covering right and wrong. Attitudes are measured by the gutment scale. Actions include good and not good. Pre-test is done in school 1 time, which is one day before the video is shown and the poster is installed on healthy food. Poster displays were held for two consecutive weeks, while video screenings were carried out on the first day the posters were installed. Posters are designed to be easy to read and understand by students. Post-test was carried out two weeks after displaying posters and showing videos. Data were analyzed using paired simple T-test to see differences in consumption behavior among students between before and after the intervention. 


\section{STRADA Jurnal Ilmiah Kesehatan}

DOI: $10.30994 /$ sjik.v9i2.229

ISSN: 2252-3847 (print); 2614-350X (online)

Vol.9 No.2 November 2020 Page.543-550

\section{RESULTS}

\section{Characteristics of Respondents}

Based on the data of the characteristics of respondents according to gender can be seen in Table 3 below:

\begin{tabular}{lccc} 
& Gender & $\mathrm{n}$ & $\%$ \\
\hline Female & 23 & 52.3 \\
Male & 21 & 47.7 \\
\hline
\end{tabular}

The results of the distribution of respondents' data according to gender can be seen that the majority of respondents in this study were female at $52.3 \%$.

\section{Univariate Analysis}

Overview of Students' Knowledge, Attitudes and Actions about Healthy Snacks

Table 4 Overview of Students' Testing of Healthy Snacks

\begin{tabular}{lllll}
\hline Variable & \multicolumn{2}{c}{ Pre test } & \multicolumn{2}{c}{ Post test } \\
\cline { 2 - 5 } & $\mathrm{n}$ & $\%$ & $\mathrm{n}$ & $\%$ \\
\hline Knowledge & & & & \\
$\quad$ Well & 28 & 63,6 & 42 & 95.5 \\
$\quad$ Enough & 15 & 34,1 & 1 & 2,3 \\
$\quad 1$ & 2,2 & 1 & 2,3 \\
\hline Less & 25 & 56,8 & 37 & 84,1 \\
Attitude & 19 & 43,2 & 7 & 15,9 \\
$\quad$ Positive & & & & \\
$\quad$ Negative & 23 & 52,3 & 38 & 86,4 \\
action & 21 & 47,7 & 6 & 13,6 \\
$\quad$ Positive & & & & \\
$\quad$ Negative &
\end{tabular}

Table 4 Shows the results of the analysis of the frequency distribution of knowledge, attitudes and actions of respondents before and after the intervention has increased. The frequency distribution of students' knowledge before the intervention was mostly in the good category with 28 (63.6\%) and after the intervention increased to 42 (95.5\%). The frequency distribution of student attitudes before intervention was mostly in the positive category as much as $25 \%(56.8 \%)$ and increasing to $37(84.1 \%)$ after the intervention. The frequency distribution of students' actions before the intervention was mostly in the positive category as many as $23(52.3 \%)$ and after the intervention increased to 38 $(86.4 \%)$.

\section{Bivariate analysis}

Table 5 Analysis of Differences in Students' Knowledge, Attitudes and Actions Before and After Intervention Education through Video and Posters at SDN 021 Pekanbaru.

\begin{tabular}{lccc}
\hline Variable & Mean & SD & $p$ value \\
\hline $\begin{array}{l}\text { Knowledge } \\
\text { Before } \\
\text { After }\end{array}$ & 0,318 & 0,471 & 0,000 \\
\hline $\begin{array}{l}\text { Attitude } \\
\text { Before } \\
\text { After }\end{array}$ & 0,250 & 0,534 & 0,03 \\
\hline
\end{tabular}




\section{STRADA Jurnal Ilmiah Kesehatan}

DOI: $10.30994 /$ sjik.v9i2.229

ISSN: 2252-3847 (print); 2614-350X (online)

Vol.9 No.2 November 2020 Page.543-550

\begin{tabular}{llll}
\hline $\begin{array}{l}\text { Action } \\
\text { Before } \\
\text { After }\end{array}$ & 0,318 & 0,960 & 0,02 \\
\hline
\end{tabular}

Table 5 shows that the results of the analysis there are differences in mean scores of students' knowledge before and after the educational intervention via video and poster is 0.318 with a standard deviation of 0.471 . Statistical test results obtained $p$ value $0,000(p$ $<0,05)$, it can be concluded that there is very significant difference in students' knowledge after being given educational intervention through video media and posters better than before being given intervention.

The difference in mean scores of students' attitudes before and after the educational intervention via video and poster is 0,250 with a standard deviation of 0,534 . Statistical test results obtained $\mathrm{p}$ value $0.03(\mathrm{p}<0.05)$, it can be concluded that there are significant differences in students' attitudes after being given educational intervention through video media and posters better than before being given intervention. The difference in mean scores of students' actions before and after the educational intervention via video and poster is 0.318 with a standard deviation of 0.960 . Statistical test results obtained $p$ value 0.02 ( $p<0.05$ ), it can be concluded that there are significant differences in student actions after being given educational intervention through video media and posters better than before being given intervention.

\section{DISCUSSION}

The results showed that the provision of health education through video and poster media had an influence on the knowledge, attitudes and actions of students in choosing healthy snacks. Based on the identification of the value of student knowledge from the results of the study there is an influence on knowledge in the selection of healthy snacks. This can be seen from the increase in average knowledge after being given edukais media through videos and posters. This assessment is based on the accuracy of students in answering questionnaires about healthy snacks knowledge which consists of types of snacks and characteristics of safe and healthy snacks, positive and negative effects of snacks, sanitation and security of snacks, foodborne diseases. Increased knowledge can be seen from the average respondent's answers at pre-test as much as $63 \%$ included in the good criteria category and increased to $95 \%$ during the post-test.

New information obtained about healthy snacks can be a new cognitive foundation for the formation of knowledge in the selection of healthy snacks (Ariandani, 2011). Knowledge is the result of knowing, and this happens after someone senses a particular object. Sensing occurs through human senses, namely the senses of sight, hearing, smell, taste, and touch. Knowledge or cognitive is an important domain for the formation of one's actions. The level of knowledge is influenced by the learning process (Notoatmodjo, 2007).

Health education is education that cannot be separated from the learning process because the learning process exists in order to achieve educational goals. A person will have a perception of what will be lived that relates to the level of knowledge gained from information, so that if the information received is not clear enough, the learning outcomes obtained are also not optimal (Notoatmodjo, 2007). Changes in knowledge gained are the result of health education. Media health education in the form of videos and posters is suitable for school-age children because it can develop children's imagination and learning activities in a pleasant atmosphere so that it can stimulate children's learning interest 


\section{STRADA Jurnal Ilmiah Kesehatan}

DOI: $10.30994 /$ sjik.v9i2.229

ISSN: 2252-3847 (print); 2614-350X (online)

Vol.9 No.2 November 2020 Page.543-550

because it is displayed in an interesting and easily understood picture. This media is quite fun in accordance with the stage of cognitive development of school-age children, the majority of respondents aged 10-11 years are in the concrete operational phase, meaning mental activities that are focused on objects of real or concrete events.

Promotional media in the form of posters have a stronger influence in improving student knowledge compared to leaflets or comics (Efriza, 20019). Poster placement placed in a place that is often seen by students will cause students to be exposed many times to see and read. This has become a good supporting factor in providing health education regarding healthy snacks to students. So that through the poster health education media it is expected that students can gain knowledge about healthy snacks through absorption of material as much as $30 \%$ of the photos they see and $10 \%$ of the information they

read.

The results of this study are in line with the Miftahusaadah study (2016) which concluded that knowledge of healthy snacks in elementary school students had increased after being given health education using digital video media. Changes in knowledge gained are the result of nutritional education by using digital video media that contains information and images about snacks so students experience interest in seeing and listening to them. Providing information using interesting digital video media and a pleasant atmosphere can make students more easily receive the information provided.

Video is an audio visual motion media which is the most complete health education media because it has sound stimuli, visuals, colors, and moving images. This uses more senses so that the messages conveyed can increase children's attention, concentration and imagination. Then the child is expected to begin to learn to apply the things learned so that eventually it can shape knowledge, attitudes and good actions in the selection of healthy snacks through the absorption of material as much as $50 \%$ of audio visual media.

The results of the study Siswi, Yunitasari, and Krisna (2014) show similar things that audio visual media is able to effectively improve the knowledge, behavior and consumption of healthy snacks in elementary school children. Good knowledge that students have about healthy snacks has an impact on students' attitudes in choosing healthy snacks. This can be seen from the attitude of students around $57 \%$ in the good category before intervention and increased to $85 \%$ after intervention. This data is strengthened by the results of statistical analysis which showed a significant difference with $p=0.03$ which means that there is an influence of educational media using videos and posters on students' attitudes in healthy snacks selection.

Attitude is a reaction that is still closed from someone to a stimulus or object. Attitudes are views, opinions, responses or judgments and also a person's feelings towards stimuli or objects that are accompanied by a tendency to act (Notoatmodjo, 2003). The attitude values of respondents after being given health education using video and posters, the majority became better because the respondents were able to capture all the positive things they got from health education. After good knowledge, then emotionally someone will react well to the stimulus. Students 'knowledge of nutrition and food security influences students' attitudes and behavior in choosing food purchased. Knowledge of nutrition and good food safety, students are expected to choose foods that are safe and nutritious (Purtiantini, 2010).

Health education media can convey suggestive messages that can direct one's opinion. If the suggestive messages are strong enough, it will provide an affective basis in evaluating things so that an attitude is formed. Videos and posters are health education media that are strong enough to provide an understanding of good and bad attitudes, as 


\section{STRADA Jurnal Ilmiah Kesehatan}

DOI: $10.30994 /$ sjik.v9i2.229

ISSN: 2252-3847 (print); 2614-350X (online)

Vol.9 No.2 November 2020 Page.543-550

well as permits and should not be done. The results showed that posters and videos (films) had a positive effect on changes in attitudes in the selection of schoolchildren snacks (Muliani, 2012).

New information obtained from the health education media can direct a person's opinion so that it can provide a new foundation of knowledge for the formation of a positive attitude. The results of this study are also supported by research conducted by Supriyadi, Kasad and Idwar, (2014) which emphasizes that good knowledge will improve student behavior in maintaining cleanliness in buying snacks.

Student actions also increase in the selection of healthy snacks after being given health education due to increased student knowledge. Health education through video media and posters has an impact on children's knowledge about the definition, benefits, effects and characteristics of healthy snacks and how to choose healthy snacks. A person's perception will arise through the process of knowing or choosing various objects related to the actions to be taken (Notoatmodjo, 2003). After that the child will apply in an action. The results of Febryanto (2016) stated that there was a correlation between knowledge and attitudes about the selection of healthy snacks with children's behavior in choosing healthy snacks, the researchers concluded that the majority of respondents had comparable knowledge, attitudes and actions. Safriana's research (2012) confirms that there is a relationship between student attitudes in choosing food and student behavior in choosing snacks at SDN Garot in Darul Imarah District, Aceh Besar District.

The results of this study are in line with the research conducted by Tampubolon (2009) which shows that the media of posters and leaflets can improve the knowledge, attitudes and actions of consuming healthy foods in high school students. One factor that has a large influence on the occurrence of a person's behavior is socio-psychological factors. These socio-psychological factors consist of attitudes, emotions, beliefs, habits, and will. Home eating habits and educational institutions where children attend school. Habit of eating breakfast at home or bringing supplies from home, habituation of foods that are balanced nutrition, not snacks at the stall when they break school. The school environment can shape eating habits for children (Rosa, 2011). Other research shows that good student knowledge about healthy snacks / drinks can prevent them from consuming food / drinks carelessly Nasution (2013).

\section{CONCLUSION}

Knowledge of students prior to intervention was in the good category as much as $63.6 \%$ and increased to $95.5 \%$ after being given health education through videos and posters. Students' attitudes before intervention were mostly in the positive category of $56.8 \%$ and increased to $84.1 \%$ after being given health education through videos and posters. The actions of students before intervention were mostly in the positive category as much as $52.3 \%$ and increased to $86.4 \%$ after being given health education through videos and posters. Media of health education through video and posters has a positive influence on knowledge $(\mathrm{p}=0,000)$, attitude $(\mathrm{p}=0.003)$, and actions $(\mathrm{p}=0.002)$ of students in choosing healthy snacks.

\section{REFERENCES}

Yasmin G, Madanijah S, Perilaku penjaja pangan jajanan anak sekolah terkit gizi dan keamanan pangan di Jakarta dan Sukabumi. Jurnal Gizi dan pangan. 2010, 5(3):148-157 


\section{STRADA Jurnal Ilmiah Kesehatan}

DOI: $10.30994 /$ sjik.v9i2.229

ISSN: 2252-3847 (print); 2614-350X (online)

Vol.9 No.2 November 2020 Page.543-550

Hardani R, Pola makan sehat. Makalah seminar online kharisma ke-2, Yogyakarta, 2012, RS dr Sardjito

Almatsier S, Prinsip dasar ilmu gizi. Jakarta, 2009, PT Gramedia pustaka utama

Pudjiadi S, Ilmu gizi klinis pada anak. Jakarta, 2000, Balai Penerbit FKUI

Ariandani B, Faktor Yang Berhubungan Dengan Pemilihan Makanan Jajanan Pada Anak Sekolah Dasar, 2011

Notoatmodjo, Promosi kesehatan dan iilmu perilaku. Jakarta, 2007, Rineka Cipta

Efriza, Efektifitas media promosi dalam meningkatkan pengetahuan siswa, guru dan pedagang tentang keamanan pangan, Tesis, 2009, Sekolah Pascasarjana Institut Pertanian Bogor

Purtiantini, Hubungan Pengetahuan dan Sikap Mengenai Pemilihan Makanan Jajanan dengan Perilaku Anak Memilih Makanan di SDIT Muhammadiyah Al Kautsar Gumpang Kartasura, Skripsi, 2010, Program S1 Gizi Universitas Muhammadiyah Kartasura

Muliani Y, Hubungan antara promosi keamanan pangan dengan sikap memilih pangan jajanan anak sekolah yang aman, Tesis, 2012, Program pasca sarjana departemen ilmu komunikasi. Universitas Indonesia

Rosa R, Pengetahuan Gizi dan Keamanan Pangan Jajanan Serta Kebiasaan Jajan Siswa Sekolah Dasar di Depok dan Sukabumi, Skripsi, 2011 Institut Pertanian Bogor

Nasution, E. Tingkat pengetahuan dan pola konsumsi makanan jajanan siswa/I SMPIT Al Fityan School Medan. JURIDIKTI, 2013, 6(3). 106-110 